\title{
Od informacji do wiedzy. Rola bibliotekarzy-informatorów w Bibliotece Uniwersyteckiej w Warszawie
}

\begin{abstract}
The University Library in Warsaw as one of the biggest academic libraries in Poland, serves a great amount of users every day. The major role in this process play the workers of Information Services and Training Department. The article presents everyday work of eight subject librarians and four employees of Information Desk. The librarians provide information activity in the wide meaning - they promote the publications, take an active part in creating the book collection, take care of the high level of users' service. The librarians also improve their skills regularly and extend professional knowledge. According to the conference's topic the author would like to point at the relationship: Professionalism $=$ information + education. Thanks to being involved in so various activities the librarians are the active participants of education process (including adult education), they become the specialists in their disciplines, advisers, library's service promoters and trainers at the same time.
\end{abstract}

Słowa kluczowe: bibliotekarz dziedzinowy, działalność informacyjna biblioteki, działalność edukacyjna biblioteki, praca z użytkownikiem

\section{Wstęp}

Biblioteka Uniwersytecka w Warszawie (BUW) jest jedną z największych bibliotek akademickich w kraju. Liczba zbiorów przekracza 3160000 jednostek (z czego ponad 500000 w wolnym dostępie), a każdego dnia odwiedza ją średnio 2 tysiące czytelników. W 2014 r. udzielono w BUW ponad 80000 informacji różnego typu ${ }^{1}$. W obliczu takich danych jest rzeczą naturalną, że istnieje silna potrzeba zorganizowania odpowiedniej służby informacyjnej. BUW jako pierwsza biblioteka uczelniana w Polsce umożliwiła swoim czytelnikom swobodny dostęp do zbiorów na taką skalę. Z jednej strony wolny dostęp ma wiele zalet, jak możliwość samodzielnego wyszukiwania odpowiedniej lektury (w tym czasopism), przeszukiwania zbiorów z pokrewnych dziedzin; ale też czasem powoduje zagubienie czytelników wśród skomplikowanej na pierwszy rzut oka Klasyfikacji Biblioteki Kongresu (KBK). Powołany w styczniu 2014 r. Oddział Usług Informacyjnych i Szkoleń (powstały z połączenia dwóch innych

\footnotetext{
${ }^{1}$ Dane liczbowe pochodzą ze Sprawozdania Biblioteki Uniwersyteckiej w Warszawie $i$ bibliotek wydziałowych za rok 2014, [dostęp: 25.05.2015], http://www.buw.uw.edu.pl/images/ BUW_PDF/sprawozdanie/sprawozdanie2014.pdf.
} 
jednostek, zbliżonych funkcjami) działa właśnie na tym polu - by ułatwić użytkownikom korzystanie z bogatych zbiorów BUW, udzielić im jak najpełniejszej informacji o zbiorach i działalności biblioteki, doradzić i wspomóc w procesie pogłębiania wiedzy. W niniejszym artykule zostanie przedstawiona działalność BUW w tym zakresie, oparta na wzorcu: Informacja $\rightarrow$ Edukacja $\rightarrow$ Wiedza.

\section{Informacja}

Działalność informacyjną BUW można podzielić na dwa uzupełniające się obszary: informację ogólną i dziedzinową ${ }^{2}$. Trzeba tu wspomnieć, że w Bibliotece Uniwersyteckiej w Warszawie zbiory ułożone są według Klasyfikacji Biblioteki Kongresu (dostosowanej do potrzeb biblioteki). Podzielono je na osiem szerokich dziedzin:

1. Język. Literatura.

2. Filozofia. Psychologia. Religia. Oświata.

3. Nauki historyczne.

4. Geografia. Nauki matematyczne, przyrodnicze i stosowane.

5. Prawo. Nauki polityczne.

6. Nauki społeczne. Antropologia.

7. Dzieła treści ogólnej. Bibliotekoznawstwo.

8. Muzyka. Architektura. Sztuki piękne.

Każdą z dziedzin opiekuje się bibliotekarz, zwany w BUW informatorem dziedzinowym. Choć literatury związanej z rolą bibliotekarzy dziedzinowych wciąż jest niewiele, podkreśla się, że ,ich zadania koncentrują się wokół potrzeb informacyjnych określonej grupy studentów lub pracowników naukowych"3. Nie inaczej jest w BUW. Do obowiązków każdego z informatorów należy przede wszystkim codzienny dyżur na swoim stanowisku. W rzeczywistości wielu $\mathrm{z}$ nas ${ }^{4}$ spędza tam o wiele więcej czasu. Podstawowym zadaniem bibliotekarza jest udzielanie wszelkiej informacji czytelnikom. W przestrzeni biblioteki książki z różnych dziedzin stoją na regałach umiejscowionych obok siebie, dlatego informatorzy nierzadko udzielają informacji dotyczącej także dziedziny sąsiedniej. Dzięki umiejscowieniu informatorów dziedzinowych $\mathrm{w}$ różnych punktach biblioteki czytelnicy zyskują stałe punkty kontaktu z bibliotekarzami ${ }^{5}$. Pomagają odnaleźć książki na półkach, wskazują

\footnotetext{
${ }^{2}$ Oczywiście wszelkiej informacji użytkownikom, którzy jej potrzebują, udzielają wszyscy bibliotekarze - w wolnym dostępie, Wypożyczalni Miejscowej, gabinetach zbiorów specjalnych.

${ }^{3}$ R. Bluck, Rozwój kadr w odniesieniu do bibliotekarzy dziedzinowych, [w:] Zarządzanie biblioteka. Najnowsze kierunki w bibliotekarstwie brytyjskim: wybór tekstów, red. I. Kemp, T. Wildhardt, Warszawa 1998, s. 146.

${ }^{4}$ Autorka referatu pracuje jako informator w dziedzinie B, L - Filozofia. Psychologia. Religia. Oświata.

${ }^{5}$ Zob. A. Jazdon, Unie venis?, [w:] Bibliotekarz dziedzinowy $w$ bibliotekach akademickich, oprac. A. Bogłowska, J. Szewczak. Torun 2001, s. 9-10.
} 
interesujące użytkownika obszary poszukiwań na konkretny temat, odpowiadają na liczne pytania związane z funkcjonowaniem całego BUW-u - wypożyczaniem materiałów, korzystaniem z obu czytelni (Czytelni Ogólnej oraz Czytelni Czasopism Bieżących i Mikroform), powielaniem materiałów bibliotecznych, korzystaniem z Internetu. Przede wszystkim jednak regularnie realizujemy kwerendy czytelników i pracowników biblioteki, związane z nasza dziedziną. Ogromna liczba źródeł, z których czytelnik może korzystać, nierzadko powoduje jego zagubienie. Zadaniem informatora dziedzinowego jest nie tyle proste ich wskazanie, co raczej połączenie czytelnika z konkretną informacją, której on poszukuje ${ }^{6}$.

Innym obszarem działalności informatorów jest uczestnictwo w gromadzeniu i rozwoju zbiorów. Bibliotekarze mają realny wpływ na kształtowanie się księgozbioru swojej dziedziny. W każdy poniedziałek i wtorek odwiedzają Oddział Gromadzenia i Uzupełniania Zbiorów (OGiUZ), dokonując tak zwanej przejrzeniówki. Oznacza to, że przeglądane są wszystkie książki, jakie w minionym tygodniu wpłynęły do biblioteki z egzemplarza obowiązkowego, darów oraz z zagranicy (kupno, wymiana) i zostaje podjęta decyzja, które z nich powinny znaleźć się w naszej dziedzinie. Ponadto każdy z informatorów postanawia, które egzemplarze znajdą się w wolnym dostępie, a które w magazynie zwartym, jak również wybiera te $\mathrm{z}$ książek, które powinny znaleźć się w zbiorach w większej liczbie egzemplarzy. Każda z wybranych pozycji jest przeglądana pod kątem zgodności jej tematyki z profilem konkretnej dziedziny i odpowiednio oznaczana wewnątrz, dając tym samym wskazówkę osobom opracowującym zbiory. Informator dziedzinowy decyduje również, które z książek przeznaczonych do wolnego dostępu będą mogły być swobodnie wypożyczane, a które powinny mieć status „Nie wypożycza się”.

Informatorzy dziedzinowi mają stały kontakt $\mathrm{z}$ pracownikami sekcji zagranicznej OGiUZ oraz Oddziałem Wydawnictw Ciągłych (OWC). Regularnie otrzymują od ich pracowników listy wymiany zagranicznej bądź oferty kupna książek i nowych tytułów czasopism, decydując, które z nich chcieliby mieć w swojej dziedzinie (a także - czy mają się znaleźć w wolnym dostępie, czy w magazynie). Liczba przeglądanych pozycji nie jest stała, przykładowo jeden z informatorów w kwietniu przejrzał 155 pozycji, w maju zaś - ponad 1100. Listy przychodzą w różnych językach - angielskim, niemieckim, rosyjskim, czeskim, węgierskim, litewskim, bułgarskim, słoweńskim i innych. Na decyzję o kupnie/przyjęciu daru danej pozycji ma wpływ wiele czynników - aktualność tematyki, zapotrzebowanie na tę problematykę wśród czytelników, język publikacji (także zróżnicowanie językowe czytelników danej dziedziny), jej charakter (skrypt, podręcznik, album, broszura i temu podobnych). Część propozycji

\footnotetext{
${ }^{6}$ Zob. P. Lyman, Technology and Education: The Role of Libraries In Teaching and Learning, [in:] Gateways to Knowledge. The Role of Academic Libraries in Teaching, Learning, and Research, ed. L. Dowler, London 1997, p. 150.
} 
zakupu konkretnych książek pochodzi od użytkowników, którzy przysyłają swoje dezyderaty pocztą elektroniczną, bądź zgłaszają takie zapotrzebowanie bezpośrednio bibliotekarzowi.

Do innych zadań informatora, związanych bezpośrednio z pracą z księgozbiorem, należą: kontrola stanu zbiorów (w razie potrzeby książki zniszczone są czasowo wycofywane z wolnego dostępu, zostaje im nadany status „W oprawie" w systemie komputerowym Virtua, a same książki są przekazywane Oddziałowi Ochrony Konserwacji Zbiorów), porządkowanie księgozbioru według KBK (wspólnie z pracownikami Oddziału Udostępniania), zwłaszcza w okresie wakacyjnym, a także współpraca przy selekcji księgozbioru.

Jak zauważa Robert Bluck, bibliotekarze dziedzinowi „,często muszą sprostać interesującym, prowokującym lub niejasnym pytaniom"”. Realizacja kwerendy zajmuje niekiedy dużo czasu, ale należy podkreślić, że w każdym przypadku bibliotekarz pozostaje w stałym kontakcie z użytkownikiem. Z pewnością niezwykle przydatna jest wiedza z konkretnej dziedziny. W BUW większość informatorów posiada wykształcenie kierunkowe związane z dziedziną, którą się zajmuje.

Drugim istotnym obszarem działalności informacyjnej OUIiS jest Informatorium, zwane potocznie kamiennym kręgiem ze względu na swój charakterystyczny wygląd. To serce biblioteki. Czterech z trzynastu pracowników Oddziału Usług Informacyjnych i Szkoleń (OUIiS) pełni tu codzienne dyżury, na zmianę przez $7 \mathrm{dni}$ w tygodniu. Ich wiedza na temat funkcjonowania BUW jest kompletna - nie tylko udzielają informacji, jak poruszać się po bibliotece, wyszukiwać książki w katalogu i je zamawiać, gdzie znajduje się konkretna dziedzina, ale także jakie są kategorie czytelników i ich uprawnienia, jak skorzystać z Internetu i co zrobić, gdy ten nie działa. Dodatkowo zarządzają kartami dostępu do stref zamkniętych, w których znajdują się gabinety zbiorów specjalnych. Bez problemu porozumiewają się z obcokrajowcami, przede wszystkim w języku angielskim, a jeden pracownik - dodatkowo w języku francuskim. Jako osoby z wieloletnim (często kilkunasto- lub kilkudziesięcioletnim) stażem pracy świetnie orientują się w strukturze BUW i wiedzą, do kogo zwrócić się ze specjalistycznym pytaniem. Opiekują się sprzętem reprograficznym, umiejscowionym bezpośrednio przy Informatorium: trzema kserografami, skanerem i drukarką, jak również komputerami dla czytelników, dostępnymi w holu katalogowym (kilkadziesiąt laptopów i komputerów stacjonarnych). Dbają o aktualność i kompletność materiałów informacyjnych - ulotek i folderów - zarówno w języku polskim, jak i angielskim.

Pracownicy Informatorium nie dopuszczają do sytuacji, w której czytelnik dochodzi od lady, nie uzyskawszy odpowiedzi na swoje pytanie. Nawet jeśli w danej chwili nie znają odpowiedzi, wiedzą, do kogo się po nią zwrócić. Jako bibliotekarze tego konkretnego działu zdajemy sobie sprawę, że od informacji

\footnotetext{
${ }^{7}$ R. Bluck, op.cit., s. 147.
} 
wszystko się zaczyna. Czytelnik dobrze poinformowany czuje się mniej zagubiony $\mathrm{w}$ tak wielkiej bibliotece, jaką jest BUW, a co za tym idzie - częściej i chętniej z niej korzysta podczas poszukiwań naukowych. Klasyfikacja Biblioteki Kongresu na pierwszy rzut oka może wydawać się skomplikowana, a układ dziedzin - zagmatwany dla kogoś, kto wcześniej korzystał z mniejszych bibliotek. Zadaniem pracowników Informatorium jest takie zaopiekowanie się czytelnikiem, by nie odszedł do lady bez wskazówek, jak dalej postępować lub - do kogo się zwrócić. Wiedza pracowników Informatorium obejmuje wszystkie aspekty funkcjonowania biblioteki, co sprawia, że jest to pierwszy i najważniejszy punkt dla każdego czytelnika, do którego wielokrotnie wraca.

Warto tu wspomnieć także o dyżurach weekendowych ${ }^{8}$. Mogą brać w nich udział wszyscy pracownicy BUW i wielu z nich chętnie korzysta $\mathrm{z}$ takiej możliwości, by być na bieżąco w temacie bezpośredniej obsługi użytkownika. Tym sposobem nawet osoby pracujące w działach ,zamkniętych”, jak na przykład akcesja czy opracowanie zbiorów, mają możliwość bezpośredniej obsługi użytkowników9. Podobnie rzecz się ma ze znaną wielu osobom akcją „BUW dla sów” - w trakcie sesji biblioteka jest czynna w tygodniu do godz. 5.00 rano. Bibliotekarz, który zostaje na nocnym dyżurze, niezależnie od miejsca, w którym na co dzień pracuje, spotyka się wtedy z wieloma pytaniami związanymi z całością zbiorów, ze wszystkimi dziedzinami BUW, z każdym aspektem funkcjonowania biblioteki. Takie zadania wymuszają zwłaszcza na nas - informatorach dziedzinowych - konieczność nieustannego dokształcania się, szczególnie z zakresu własnej dziedziny, o czym mowa jest w kolejnej części artykułu.

Od 11 maja 2015 r. w BUW działa nowa usługa dla czytelników - internetowy czat „Zapytaj nas online”, który umożliwia szybki kontakt z bibliotekarzem w czasie rzeczywistym za pomocą programu Libsmart Assistant. Dyżury przy jego obsłudze pełnią wszyscy pracownicy Oddziału, łącznie z kierownikiem, a zatem 13 osób. Czat działa od poniedziałku do piątku w godz. 9.00-21.00, każdy z bibliotekarzy dyżuruje co najmniej godzinę dziennie $^{10}$. Ponieważ program został uruchomiony zaledwie miesiąc temu, wciąż prowadzimy akcję reklamującą nową usługę i zachęcającą do korzystania z niej. Nadal czytelnicy wolą zadzwonić do biblioteki i tą drogą uzyskać potrzebne informacje, ale zauważamy, że z czatu korzysta coraz więcej osób. Tą drogą przesyłane są zapytania związane zarówno $\mathrm{z}$ funkcjonowaniem biblioteki, wyszukiwaniem zbiorów, jak również na przykład z kontami kaucyjnymi,

\footnotetext{
${ }^{8} \mathrm{~W}$ soboty BUW jest czynny w godz. $12.00-19.00$, natomiast w niedziele w godz. 15.00 21.00 .

${ }^{9}$ Artur Jazdon pisze wprost, że „bibliotekarzom, pracującym dotąd na spokojnym zapleczu, dobrze robi praca z czytelnikiem". Zob. A. Jazdon, op.cit.

${ }^{10} \mathrm{Nad}$ grafikiem dyżurów czuwa wyznaczona do tego osoba, co tydzień jest on uaktualniany.
} 
czyli tematem nieczęsto spotykanym w naszej codziennej pracy. To już kolejny dowód na to, jak wszechstronną wiedzą muszą dysponować pracownicy OUIiS, by móc udzielić użytkownikom pełnej i satysfakcjonującej odpowiedzi.

\section{Edukacja}

Na jakość obsługi informacyjnej użytkowników niemały wpływ ma edukacja, rozpatrywana $z$ dwóch stron: edukacji czytelników oraz edukacji bibliotekarzy, którzy podnoszą swoje kompetencje.

Regularnie od lat prowadzone są w BUW szkolenia biblioteczne - metodą tradycyjną oraz online ${ }^{11}$. Oprócz przekazywania użytkownikom takich podstawowych informacji, jak korzystanie z katalogu, wypożyczanie zbiorów, korzystanie z czytelni czy wolnego dostępu, staramy się również zwrócić ich uwagę na samodzielne wyszukiwanie informacji oraz rolę informatorów dziedzinowych.

Oprócz tradycyjnego szkolenia bibliotecznego, wyjaśniającego (zwłaszcza studentom pierwszego roku), jak korzystać z biblioteki i jej zbiorów, pracownicy Oddziału Usług Informacyjnych prowadzą liczne szkolenia dla użytkowników pod wspólna nazwą, „Wiedza nie leży na ulicy. Znajdziesz ją w BUW!"12. W chwili obecnej dostępnych jest siedem różnych szkoleń:

1. „Elektroniczne bazy prawnicze na UW”.

2. „Jak sobie poradzić z listą lektur?”

3. „Jak szukać, by nie błądzić, czyli o sposobach wyszukiwania w nowym katalogu online bibliotek UW".

4. „Legalnie do celu - o prawie autorskim w nauce”.

5. „Mocna strona Internetu. Zasoby elektroniczne na Uniwersytecie Warszawskim".

6. „Porządek rzeczy, czyli jak sporządzać przypisy i bibliografię załącznikową".

7. „Zasoby elektroniczne dla historyków sztuki i architektów dostępne na UW".

Wszystkie szkolenia są bezpłatne i trwają z reguły 90 minut. Zapisać się na nie może każdy czytelnik BUW. Szkolenia są prowadzone z wykorzystaniem prezentacji multimedialnych, w formie warsztatowej. Użytkownikom zaoferowano dwa terminy. Spotkania odbywają się z reguły dla 1 do 8-10 osób. Powstał również film promujący ofertę OUIiS ${ }^{13}$. Do końca 2014 r. (szkolenia

${ }^{11}$ W 2014 r. przeszkolono 947 osób metodą tradycyjną, formę online wybrało 5557 studentów (z czego 3750 osób zaliczyło test końcowy). Z prowadzonego raz w miesiącu przysposobienia bibliotecznego dla chętnych skorzystało 10 osób (dane liczbowe pochodzą ze Sprawozdania Biblioteki Uniwersyteckiej w Warszawie i bibliotek wydzialowych za rok 2014).

${ }^{12}$ Oferta szkoleń Biblioteki Uniwersyteckiej w Warszawie, [dostęp: 18.05.2015], http:// www.buw.uw.edu.pl/index.php?option=com_content\&task=view\&id=1904.

${ }^{13}$ Szkolenia w BUW, [dostęp: 18.05.2015], https://www.youtube.com/watchv=YBnVO UUE0mM. 
oferowane są od października 2014 r.) przeszkolono ogółem 100 osób ${ }^{14}$, a na przyszły rok akademicki planowane jest uruchomienie dodatkowych warsztatów. Warto również wspomnieć, że w pierwszej fazie przygotowywania szkoleń zostały one przeprowadzone najpierw dla pracowników macierzystego oddziału, a następnie dla innych chętnych pracowników BUW. Wszystkie uwagi zostały uwzględnione, a dzięki takim „pre-szkoleniom” mieliśmy możliwość nie tylko dostrzeżenia pewnych usterek i braków, nad którymi należało jeszcze popracować, ale również sprawdzenia się w roli edukatorów. Takie doświadczenia są dla nas bardzo cenne.

Niezwykle wartościowe są również szkolenia wewnętrzne, organizowane przez inne oddziały biblioteki, między innymi z podstaw mikrofilmowania, baz elektronicznych, obsługi modułu wypożyczeń czy katalogowania. Dzięki temu nie tylko poszerzamy swoją wiedzę, ale także możemy uczestniczyć w większej liczbie aktywności. Dzięki obszernemu szkoleniu z katalogowania w systemie Virtua można na przykład zdobyć uprawnienia wymagane w pracy przy Repozytorium Uniwersytetu Warszawskiego ${ }^{15}$. Pozwala to na większą samodzielność w pracy, a także jej różnorodność. W BUW odbywają się również szkolenia realizowane z potrzeby chwili. Na Uniwersytecie istnieje możliwość wzięcia udziału w ciekawych szkoleniach dla pracowników nie będących nauczycielami akademickimi, na przykład z języka angielskiego czy kontaktu z klientem. W tym ostatnim szkoleniu szczególnie chętnie wzięli udział pracownicy Informatorium, którzy pracują jako obsługa pierwszej linii. Pracownicy OUIiS często uczestniczą także w różnych wydarzeniach organizowanych w samej bibliotece, takich jak spotkania Klubu pod Otwartą Księgą, Autorskie Czwartki w BUW, liczne seminaria naukowe, konferencje, wernisaże wystaw i temu podobnych, które także poszerzają naszą wiedzę.

Eksplozja informacji, jakiej obecnie doświadczamy sprawiła, że problemem nie jest jej brak, ale raczej nadmiar. Wymaga się od nas, bibliotekarzy, nowych umiejętności - selekcji informacji, określenia ich jakości i zarządzania danymi. Z drugiej strony ,postawa i stan umiejętności personelu kontaktowego ma znaczenie podstawowe, gdyż decyduje o zadowoleniu użytkowników i dobrej opinii o bibliotece" ${ }^{16}$. Z tego względu zdecydowanie stawiamy na dokształcanie się, zarówno w kwestii wiedzy specjalistycznej, bibliotekarskiej i dziedzinowej, jak również tej związanej z rozwojem kompetencji miękkich.

${ }^{14}$ Dane liczbowe pochodzą ze Sprawozdania Biblioteki Uniwersyteckiej w Warszawie $i$ bibliotek wydziatowych za rok 2014 [dostęp: 25.05.2015], http://www.buw.uw.edu.pl/images/ BUW_PDF/sprawozdanie/sprawozdanie2014.pdf. ceon.pl/.

${ }^{15}$ Repozytorium Uniwersytetu Warszawskiego, [dostęp: 15.05.2015], https://depotuw.

${ }^{16} \mathrm{~S}$. Bielawska, Marketing wewnętrzny źródtem sukcesu nowoczesnej biblioteki akademickiej, [w:] Unowocześnianie organizacji i metod pracy bibliotek $w$ świetle zmieniajacych się potrzeb czytelników. Edycja II. Materiały konferencyjne, Opole, 16-17 listopada 2011 r., red. W. Matwiejczuk, D. Szewczyk-Kłos, Opole 2012, s. 205. 


\section{Podsumowanie}

Bibliotekarze całego Oddziału poszerzają swoją wiedzę i umiejętności również na zewnętrznych konferencjach i szkoleniach, by potem móc przekazać ją naszym czytelnikom. Pracownicy Oddziału Usług Informacyjnych i Szkoleń zajmują się także wieloma innymi sprawami, przyjmując na siebie kolejne nowe zadania, mające ułatwić czytelnikom poruszanie się w BUW i zwiększyć przyjemność korzystania z biblioteki. Zbigniew Żmigrodzki zwracał uwagę na potrzebę ,aktywności w kontaktach z użytkownikami, wychodzenia poza stereotypowe usługi $\mathrm{w}$ stronę twórczych inicjatyw i pośrednictwa w dalej idących poszukiwaniach"17. Jesteśmy podobnego zdania - staramy się, by nasze działania promowały pracę naszego zespołu, ale także BUW jako całości. W chwili obecnej edukacja użytkowników, jaką prowadzimy, przyjmuje wiele wymiarów (oprócz tych najbardziej oczywistych, wymienionych we wcześniejszej części artykułu):

- oprowadzanie wycieczek po bibliotece, zarówno dla grup szkolnych, bibliotekarzy, osób z zewnątrz, jak i gości zagranicznych - wycieczki prowadzone są w językach polskim, angielskim, niemieckim lub rosyjskim; ich głównym celem jest przedstawienie BUW jako książnicy uniwersyteckiej, naukowej, ale pełniącej także funkcje biblioteki publicznej, promowanie naszych działań oraz wyjaśnienie sposobu funkcjonowania biblioteki (dużym zainteresowaniem cieszy się także sam budynek oraz piękny ogród na dachu);

- $\quad$ prowadzenie profilu BUW na Facebooku - promujemy tam nasze szkolenia, wszelkie akcje odbywające się na terenie biblioteki (koncerty, wystawy, wykłady i inne), imprezy odbywające się w różnych jednostkach UW, a także ciekawe zasoby internetowe;

- tworzenie i aktualizacja materiałów informacyjnych - folderów, ulotek, zakładek, tymczasowych plakatów i temu podobne;

- aktualizowanie strony WWW biblioteki poprzez umieszczanie na niej wszelkich istotnych informacji związanych z funkcjonowaniem BUW;

- $\quad$ opieka nad Repozytorium UW;

- $\quad$ pisanie artykułów na bUWloga ${ }^{18}$.

Aktualizowanie swojej wiedzy i zdobywanie nowych umiejętności, stały rozwój - to ważne wyznaczniki profesjonalizmu. Obecny świat rozwija się w ogromnym tempie, a ,dostosowanie bibliotek do zmieniającego się świata i nowych potrzeb jej użytkowników jest dzisiaj ważnym problemem" "19. Współczesny użytkownik ma o wiele większe wymagania niż kiedyś, informator

${ }^{17}$ Z. Żmigrodzki, Biblioteki w XXI wieku: tendencje i zagrożenia, [w:] Unowocześnianie organizacji i metod pracy bibliotek $w$ świetle zmieniajacych się potrzeb czytelników. Materialy z konferencji (Opole, 8 listopada 2001), red. W. Hendzel, W. Matwiejczuk, Opole 2002, s. 26-27.

${ }^{18}$ bUWlog, [dostęp: 16.05.2015], http://buwlog.uw.edu.pl/.

${ }^{19}$ Z. Żmigrodzki, Biblioteka $w$ obliczu przemian, [w:] Unowocześnianie organizacji $i$ metod pracy bibliotek w świetle zmieniajacych się potrzeb czytelników. Edycja II..., s. 27. 


\section{4}

dziedzinowy odgrywa zatem ogromna rolę w dostarczaniu wiarygodnej informacji, która będzie miała szanse przekształcić się w konkretną wiedzę ${ }^{20}$. Z tego względu pracownicy informacji w BUW są bardzo aktywni i wielozadaniowi. Mieszane stanowisko pracy, na którym nie wykonuje się wciąż jednej i tej samej czynności rozbudza i zwiększa kreatywność i wydajność, ale również zapewnia dużą satysfakcję z pracy osobom, które szukają tego typu zajęcia i dobrze się czują w roli edukatorów, informatorów i współtwórców procesów naukowo-dydaktycznych.

Warto podkreślić współistnienie informacji i edukacji, które doskonale widać na przykładzie pracy informatora w BUW. Duża liczba kontaktów z czytelnikiem rzeczywiście opiera się na prostej informacji - gdzie znajduje się konkretna dziedzina, jak się zapisać do biblioteki, co oznacza biała naklejka na książce i temu podobne. Jednak w wielu przypadkach, kiedy czytelnik poszukuje zbiorów z konkretnej, nierzadko wąskiej tematycznie gałęzi wiedzy, udzielenie informacji przekształca się w proces edukacyjny. Bibliotekarz przeprowadza czytelnika sobie dobrze znaną, a użytkownikowi nową ścieżką - począwszy od sposobu wyszukiwania w katalogu, poprzez liczne bazy elektroniczne dostępne na UW (obie czynności z włączeniem zawężania wyników dzięki fasetom, o których wielu nowych użytkowników nie wie), dziedzinowe, specjalistyczne bazy dostępne w Internecie, aż do katalogów centralnych (NUKAT, KaRo, WorldCat ${ }^{21}$ ) i bibliotek rzadziej wykorzystywanych w procesie kształcenia (na przykład muzealnych czy kościelnych) oraz zbiorów dostępnych w Internecie na wolnych licencjach. Bezpośredni kontakt z czytelnikiem w takiej sytuacji edukacyjnej jest niezwykle cenny. Daje okazję do promowania biblioteki w ogóle, jak również udzielania konkretnej informacji związanej ze zbiorami własnymi oraz innych bibliotek, budując w ten sposób wizerunek biblioteki jako instytucji rzetelnej, przyjaznej i otwartej na czytelnika. Podpierając się tytułem niniejszej konferencji, należy zauważyć, że wiarygodna informacja oraz wszechstronna edukacja oferowane przez bibliotekarzy budują profesjonalizm usług BUW, który zdecydowanie należy do naszych priorytetów.

${ }^{20}$ „By facilitating high levels of communication and collaboration between stakeholders, reference librarians help ensure the LC will meet the high expectations and demands of the modern user. The reference librarian will continue to play a vital role in the synthesis of information into knowledge and knowledge into wisdom, which supports the goal of the LC and the overall mission of higher education". Zob. J.A. Wolfe, T. Naylor, J. Drueke, The Role of the Academic Reference Librarian in the Learning Commons, „Referencje \& User Services Quaterly” 2010, vol. 50, issue 2, p. 5 .

${ }^{21}$ NUKAT - Narodowy Uniwersalny Katalog Centralny; KaRo - Katalog Rozproszony Bibliotek Polskich. 


\section{Bibliografia}

Al-khatib A.H., Rola bibliotekarza dziedzinowego w wolnym dostępie, „Biuletyn EBIB” 2000, nr 8, [dostęp: 12.04.2015], http://www.oss.wroc.pl/biuletyn/ebib18/hakim.html.

Bielawska S., Marketing wewnętrzny źródtem sukcesu nowoczesnej biblioteki akademickiej, [w:] Unowocześnianie organizacji i metod pracy bibliotek $w$ świetle zmieniajacych się potrzeb czytelników. Edycja II. Materiały konferencyjne, Opole, 16-17 listopada 2011 r., red. W. Matwiejczuk, D. Szewczyk-Kłos, Opole 2012, s. 205.

Bluck R., Rozwój kadr w odniesieniu do bibliotekarzy dziedzinowych, [w:] Zarzadzanie biblioteka. Najnowsze kierunki w bibliotekarstwie brytyjskim: wybór tekstów, red. I. Kemp, T. Wildhardt, Warszawa 1998, s. 146.

bUWlog, [dostęp: 16.05.2015], http://buwlog.uw.edu.pl/.

Głowacka E., Problem funkcji informacyjnej biblioteki uniwersyteckiej, Torun 1992.

Jazdon A., Unde venis?, [w:] Bibliotekarz dziedzinowy w bibliotekach akademickich, oprac. A. Bogłowska, J. Szewczak. Toruń 2001, s. 9-10.

Li, L., Emerging Technologies for Academic Libraries in the Digital Age, Oxford 2009.

Lyman P., Technology and Education: The Role of Libraries In Teaching and Learning, [w:] Gateways to Knowledge. The Role of Academic Libraries in Teaching, Learning, and Research, red. L. Dowler, London 1997, s. 150.

Oferta szkoleń Biblioteki Uniwersyteckiej w Warszawie, [dostęp: 18.05.2015], http://www. buw.uw.edu.pl/index.php?option=com_content\&task=view\&id=1904.

Repozytorium Uniwersytetu Warszawskiego, [dostęp: 15.05.2015], https://depotuw.ceon.p1/.

Sprawozdanie Biblioteki Uniwersyteckiej w Warszawie i bibliotek wydziatowych za rok 2014 [dostęp: 25.05.2015], http://www.buw.uw.edu.pl/images/BUW_PDF/sprawozdanie/spra wozdanie2014.pdf.

Wolfe J.A., Naylor T., Drueke J., The Role of the Academic Reference Librarian in the Learning Commons, „, Referencje \& User Services Quaterly” 2010, vol. 50, issue 2, p. 5.

Żmigrodzki Z., Biblioteki w XXI wieku: tendencje i zagrożenia, [w:] Unowocześnianie organizacji i metod pracy bibliotek $w$ świetle zmieniajacych się potrzeb czytelników. Materiaty $z$ konferencji (Opole, 8 listopada 2001), red. W. Hendzel, W. Matwiejczuk, Opole 2002, s. 26-27. 